\title{
Penerapan Prinsip Shiddiq dan Amanah Pada Usaha Layanan Internet di Kota Kendari
}

\author{
Sagibran Agid Birambi \\ Universitas Halu Oleo \\ gibranagid1@gmail.com \\ Ernawati \\ Universitas Halu Oleo \\ ernawaty@uho.ac.id
}

\begin{abstract}
Abstrak Penelitian ini bertujuan untuk mengetahui tingkat penerapan prinsip shiddiq dan amanah pada pengelolaan usaha jasa layanan internet di Kota Kendari. Sampel ditentukan secara cluster random sampling, dengan total 10 warnet. Analisis data dilakukan secara deskriptif. Adapun indikator shiddiq yaitu: (1) jujur dalam menyampaikan informasi mengenai kerusakan/gangguan jaringan, (2) ketersediaan tarif yang telah tertera; (3) penyampaian kenaikan tariff, sementara manah yaitu: (1) upaya pengelola memblokir situs yang mengandung pornografi dan pornoaksi; dan (2) tanggungjawab pengawasan terhadap terhadap upaya pembukaan situs yang mengandung pornografi dan pornoaksi serta kekerasan lainnya. Hasil penelitian menunjukkan bahwa tingkat penerapan prinsip shiddiq dalam pengelolaan usaha jasa layanan internet di Kota Kendari berada pada penerapan syariah tinggi yakni sebesar 76.67 persen. Indikator shiddiq yang masih rendah diterapkan yaitu keterbukaan pengelola usaha dalam penyampaian kenaikan tarif. Adapun tingkat penerapan prinsip amanah dalam pengelolaan usaha jasa layanan internet berada pada kategori sangat rendah yakni sebesar 20.00 persen, disebabkan oleh rendahnya partisipasi pengelola dalam memblokir situs yang bertentangan dengan syariah, maupun dalam pengawasan akses situs yang dapat merusak moral generasi muda.
\end{abstract}

\section{Kata Kunci Shiddiq, amanah, bisnis}

\section{PENDAHULUAN}

Karakteristik berbisnis seorang muslim sebagaimana dicontohkan oleh Rasulullah diantaranya adalah shidiq (jujur) dan amanah (tanggung jawab). Kata shiddiq terulang sebanyak 155 kali dalam al-Quran yang terdapat pada 51 surat dan 144 ayat, dan arti kata siddiq diantaranya benar dan atau jujur, sedekah, dan teman (Almunadi, 2016). Amanah terkait dengan kebajikan dalam dunia bisnis, diantaranya diwujudkan dengan tanggungjawab sosial pelaku bisnis terhadap ekstenalitas negatif dari bisnis yang dikelolanya.

Salah satu bisnis yang memiliki ekstenalitas negatif bagi pengguna adalah usaha jasa layanan internet. Internet berfungsi sebagai sarana berkomunikasi, fasilitas untuk promosi dan sarana untuk mendukung pelajar dan mahasiswa dalam mencari kebutuhan 
akademiknya. Internet juga berfungsi menjadi penghubung antara satu dengan lainnya di berbagai lokasi di seluruh dunia. Konektivitas yang tercipta arus komunikasi internet membentuk jaring laba-laba dan terdiri dari titik-titik yang saling berhubungan.

Dengan demikian, selain internet dapat memenuhi kebutuhan penggunakan akan hiburan, juga berfungsi sebagai bisnis, pendidikan, hingga silaturahim. Bagi pelaku bisnis jasa layanan internet, tentu saja kebutuhan konsumen merupakan peluang bisnis yang dapat dimanfaatkan guna menghasilkan keuntungan. Alasan pelajar menggunakan internet yaitu: tuntutan belajar, murah dan mudah diakses, dan hobi untuk kesenangan. Studi juga menemukan bahwa pelajar sangat mengetahui ketersediaan warnet privat, dimana orang lain tidak akan mengetahui aktivitas dalam bilik warnet. Bahkan pelajar mengetahui bahwa warnet sering dijadikan tempat praktik pornografi, maupun sekedar mendownload gambar atau vidio asusila, serta permainan game on line yang menghabiskan waktu (Sulaiman, 2011).

Dengan demikian dalam hal menjalankan usaha jasa layanan internet para pemilik maupun pengelolala seharusnya pengawasan operasional dalam meminimalkan dampak negatif internet, demi menjaga moralitas pelanggan. Sebab bisnis tidaklah bebas nilai, sebab tujuan bisnis tidak dapat dicapai dengan menghalalkan segala cara. Sehingga bisnis dan moral merupakan dua sisi mata uang. Karena itu, usaha maksimisasi laba harus dibatasi oleh tanggung jawab terhadap dampak bisnis. Karena bisnis tidak hanya berdampak pelaku usaha, namun juga bagi masyarakat, maupun perekonomian suatu bangsa. Dalam bisnis telah banyak contoh praktik ketidakjujuran, seperti dalam penggunaan pengawet makanan, pencampuran antara produk berkualitas baik dengan berkualitas buruk, 'mengakali' agar produk yang dijual meningkat berat/timbangannya, dan lain sebagainya, akibatnya berdampak bagi peningkatan biaya bagi masyarakat berupa mahalnya biaya hidup, sehingga berdampak buruk bagi perekonomian (Alimuddin dkk, 2011).

Dampak negatif ketidakjujuran terhadap perekonomian membutuhkan pelaku-pelaku bisnis yang bertanggungjawab. Tanggungawab merupakan salah satu dimensi amanah. Amanah berhubungan langsung dengan tugas manusia sebagai khalifah dimuka bumi. Tidak hanya terkait dengan Sang Pencipta, atau rekanan bisnis pelanggan dan pemasok, namun makna khalifah terkait dengan kaberlangsungan kehidupan manusia secara umum. Sebagai khalifah, pebisnis memiliki kewajiban untuk menjaga keberlangsungan hidup manusia dari 'kerusakan' sebagai dampak layanan bisnis yang diberikan. Ketika seorang khalīfah tugasnya adalah untuk menegakan hukum-hukum Allah, maka Allah memerintahkan kepadanya untuk tidak mengikuti hawa nafsunya (Lisnawati, Abdussalam, \& Wibisana, 2015) dan berupaya mencegah perbuatan munkar, sebagaimana tertera dalam hadis Nab̄i, yang artinya, "Dari Abu Sa'ìd al-Khudri r.a. ia berkata, "Aku mendengar Rasūlullah Saw. bersabda: "Barangsiapa diantara kalian melihat kemunkaran, maka hendaklah ia merubahnya dengan tangannya, jika tidak mampu, maka dengan lisannya, dan jika tidak mampu maka dengan hatinya. Yang demikian itu selemah-lemahnya iman" (HR. Muslim). Oleh karena itu penelitian ini mengkaji bagaimana perilaku shiddiq dan amanah pelaku usaha jasa layanan internet di Kota kendari.

\section{LANDASAN TEORI}

Tujuan penciptaan manusia adalah untuk beribadah (QS. adz-Dzaariyaat: 56), ibadah dapat bermakna khusus maupun luas. Ibadah bermakna khusus merupakan ibadah yang tercermin dalam rukun Islam. Sementara ibadah bermakna luas, seperti muamalah 
termasuk di dalamnya berbisnis. Dalam kaedah fiqh dijelaskan bahwa hukum dasar muamalah adalah boleh kecuali ada dalil yang mengharamkannya (Djazuli, 2011). Prinsip muamalah terdiri dari prinsip umum dan khusus. Beberapa prinsip umum yaitu: (1) kebolehan dalam melakukan aspek muamalah, (2) muamalah dilakukan atas pertimbangan kemaslahatan, (3) muamalah memperhatikan nilai keseimbangan, dan (4) muamalah lakukan dengan pemeliharaan terhadap nilai-nilai keadilan dan menghilangkan unsur kezaliman. Adapun prinsip khusus muamalah terdiri dari: (1) aktivitas yang diperintahkan seperti: objek transaksi halal, adanya keridhaan pihakpihak yang bermualamah, dan amanah; (2) aktivitas yang dilarang seperti: riba, gharar, tadlis, dan larangan lainnya yang menyebabkan akad muamalah batal (Djamil, 2013).

Nabi Muhammad SAW mengajarkan beberapa prinsip yang telah dipraktikkan oleh bisnis modern, seperti: (1) customer oriented, yang dilakukan oleh Rasulullah melalui perilaku jujur, adil, dan tanggung jawab dalam perjanjian bisnis. (2) transp mengenai mutu, kuantitas, komposisi, bahkan susunan unsur kimia dan sebagainya atas produk yang; (3) persaingan sehat; dan (4) fairness atau keadilan(Norvadevi, 2015). Dengan demikian, pencapaian kemaslahatan bisnis dalam Islam bukan berarti menghalalkan segala cara. Sebab sejatinya tujuan bisnis Islam adalah juga keberkahan selain materi, manfaat nonmateri, dan keberlangsungan dan pertumbuhan usaha (Yusanto \& Widjajakusuma, 2002).

Dengan demikian, motivasi berbisnis atau beraktivitas dalam Islam, berbeda dengan pandangan konvensional. Beberapa teori motivasi konvensional hanya merujuk pada tujuan utama perbuatan manusia sebatas aspek duniawi, baik orientasi kebendaan, prestise maupun kenyamanan/keamanan. Meskipun terdapat beberapa teori memaparkan motivasi pebuatan manusia, namun belum sepenuhnya memberi perhatian pada aspek spiritual (Rahmawaty,2012). Maslow membahas motivasi perbuatan sebagai dorongan kebutuhan manusia. Kebutuhan paling manusia dasar yaitu fisiologis, kemudianingkatan berikutnya trasa aman, selanjutnya kebutuhan sosial sosial, kebutuhan harga diri, dan yang tertinggi merupakan kebutuhan aktualisasi diri (Andjarwati, 2015). Sementara menurut Mc Clelland (1961), kebutuhan manusia di dalamnya selain kebutuhan akan prestasi, juga manusia meiliki kebutuhan akan sosial serta dorongan manusia untuk mengatur (Prihartanta, 2015).

Motivasi manusia beraktivitas (termasuk dalam berbisnis), bukan hanya mencapai kebutuhan fisiologis dan psikologis namun juga kebutuhan spiritual. Motivasi fisiologis adalah dorongan perbuatan manusia yang tekait dengan pemenuhan kebutuhan fisikbiologi, sementara dorongan psikologis yaitu motivasi yang terkait dengan kebutuhan psikologis, seperti penghargaan dan rasa cinta. Sementara dorongan perbuatan manusia aspek spiritual adalah dorongan yang berhubungan dengan dimensi spiritual dalam pemenuhan kebutuhan, seperti dorongan aktualisasi diri dan perintah agama (Baharuddin' 2007).

Perbuatan manusia dalam Islam, apapun pencapaiannya disimpul dalam motivasi spiritual. Spirituallah penggerak segala aktivitas seorang muslim. Ketika memutuskan perbuatan apa yang harus dilakukan dan atau memilih diantara 2 aktivitas, maka dasar pertimbangannya adalah spiritual, bukan kemaslahatan, sebagaimana pesan dari Qs. Al Baqarah: 285, sami'na waata'na: saya dengar dan saya taat. Pertimbangan kemaslahatan dilakukan jika tidak ada dalil yang menjelaskankannya. Pandangan Islam tentang maslahat jika memiliki dua unsur yaitu kepatuhan syari" ah dan kebaikan serta tidak menimbulkan mudarat atau kerugian meskipun pada satu aspek (Djamil, 2013). Dengan demikian, maslahat dimata manusia, belum tentu maslahat dimata agama. Kemaslahatan 
dalam Islam yaitu tercapainya tujuan syariah yang terwujud dalam terpeliharanya kebutuhan primer menurut Islam, yaitu: agama, jiwa, akal, harta, dan keturunan; dan juga bahwa maslahat yang dibenarkan merupakan maslahat yang sejalan dengan dalil (MUI, 2005). Dalam aktivitas bisnis, agar maslahat aktivitas bisnis tidak bertentangan dengan dalil, maka salah satunya dibatasi oleh landasan etika bisnis.

Prinsip pokok etika bisnis Islam yaitu tauhid dan keseimbangan. Keyakinan ajaran tauhid mendorong seorang muslim untuk berbuat semata-mata karena Allah. Selanjutnya, prinsip keseimbangan mendorong manusia untuk yakin bahwa Allah menciptakan segala sesuatu dengan serasi dan seimbang (Baedowi, 2011). Etika bisnis al-Ghazali dibangun berdasarkan prinsip antara lain: niat baik, kejujuran, keseimbangan target dunia dan akhirat, keseimbangan aantara kepentingan pribadi dan sosial, serta ihsan (Hafidz, Sya'roni \& Marlina, 2012). Perwujudan dari keseimbangan pribadi dan sosial melahirkan etika tanggung jawab pelaku bisnis terhadap kehidupan sosial.

Tanggung jawab kehidupan sosial perusahaan salah satunya dapat diwujudkan dengan produk atau jasa apapun yang dihasilkan oleh produsen hendaklah tidak memberikan eksternalitas negatif yang akan mengganggu akal manusia. Oleh karena itu, Islam melarang mengkonsumsi maupun memproduksi makanan dan minuman yang dapat merusak akal karena akan mengancam keberadaan akalnya (Lahuri, 2013). Pertanggungjawaban atau al amanah, menunjukkan bahwa segala kebebasan dalam melakukan bisnis tetap dalam koridor bebas bertanggungjawab, sebagaimana tuntutan dalam Qs. Al Mudatsir ayat 38, yang artinya bahwa: "tiap-tiap diri bertanggung jawab atas apa yang telah diperbuatnya".

Studi tentang penerapan etika bisnis telah dilakukan sebelumnya oleh beberapa peneliti, yang menunjukkan bahwa pelaku usaha belum memenuhi etika bisnis Islam, yang diindikasikan dengan kecurangan dalam menggunakan timbangan sehingga merugikan konsumen (Darmawati, 2012). Pada sisi lain, studi dampak penerapan etika bisnis terhadap keberhasilan usaha juga telah dilakukan sebelumnya, dimana penerapan etika bisnis akan meningkatkan keuntungan usaha (Anindya, 2017) maupun dampak positif bagi aspek operasional perusahaan lainnya, seperti aspek pemasaran, aspek manajemen dan sumberdaya manusia, aspek hukum, aspek sosial, dan aspek lingkungan, serta aspek finansial (Sampurno, 2016).

\section{METODOLOGI PENELITIAN}

Penelitian ini dilaksanakan di Kota Kendari, dengan populasi seluruh pengelola jasa layanan internet yang tersebar pada 7 Kecamatan atau sebanyak 22 warnet. Sampel ditentukan dengan metode cluster random sampling sehingga terpilih 10 dari 22 warnet sebagai perwakilan dari kecamatan di Kota Kendari. Data penelitian bersumber dari data primer, yaitu data yang diperoleh secara langsung dari responden atau yang menjadi sampel penelitian. Data primer dalam penelitian ini terdiri dari tanggapan pengelola usaha terhadap penerapan prinsip shiddiq dan amanah. Pengumpulan data menggunakan kuisioner.

Variabel yang diteliti adalah shiddiq dan amanah. Shiddiq mengandung pengertian kejujuran. Kejujuran dalam bisnis terkait kejujuran dalam harga dan kualitas jasa yang diberikan. Dengan demikian, indikator yang dibangun dari variabel shiddiq dalam pengelolaan warnet yaitu: (1) selalu jujur dalam menyampaikan informasi mengenai kualitas (gangguan) jaringan, (2) ketersediaan tarif yang telah tertera; (3) penyampaian kenaikan tarif harga sewa. Pada sisi lain, indikator terpercaya (amanah), dalam penelitian ini terdiri dari: (1) upaya pengelola memblokir situs yang mengandung 
pornografi dan pornoaksi; (2) tanggungjawab pengawasan terhadap terhadap upaya pembukaan situs yang mengandung pornografi dan pornoaksi serta kekerasan lainnya. Data dianalisis melalui deskriptif kuantitatif dengan bantuan distribusi frekuensi. Skala pengukuran menggunakan Skala Guttman, yang ditentukan melalui kesimpulan dari kuisioner yang diberikan, dimana jawaban yang mengarah kepada kesimpulan 'ya' dinilai dengan skor= 1 sedangkan jawabanmengarah pada kesimpulan 'tidak' dinilai dengan skor $=0$. Adapun tingkat penerapan prinsip syariah dihitung dengan rumus:

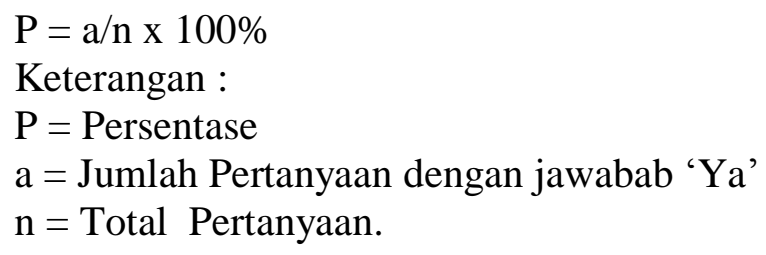

Adapun kriteria tingkat penerpan prinsip syariah dalam pengelolaan jasa layanan internet disajikan sebagaimana tabel 1.

Tabel 1. Kriteria Tingkat Penerapan Prinsip Amanah dan Terpercaya

\begin{tabular}{lll}
\hline No. & Persentase $(\%)$ & Kriteria \\
\hline 1 & $81-100$ & Sangat Tinggi \\
2 & $61-80$ & Tinggi \\
3 & $41-60$ & Rendah \\
4 & $21-40$ & Sangat Rendah \\
5 & $0-20$ & Sangat Rendah Sekali \\
\hline
\end{tabular}

Sumber: Riduwan, 2015

\section{HASIL PENELITIAN}

Hasil Penerapan prinsip untuk berprilaku benar dan jujur pada pengelolaan usaha warnet di Kota Kendari ini ditinjau berdasarkan 3 unsur yakni : (1) selalu jujur dalam menyampaikan informasi mengenai kerusakan/gangguan jaringan, (2) ketersediaan tarif yang telah tertera; (3) penyampaian kenaikan tarif harga sewa. Hasil penelitian menunjukkan bahwa penerapan prinsip untuk berperilaku shiddiq sebagaimana tabel 2 , berada pada kategori tinggi, dengan tingkat penerapan $76,67 \%$. Tingginya penerapan prinsip shiddiq pada dasarnya sejalan dengan penerapan usaha warnet yang jujur dalam menyampaikan informasi mengenai kerusakan/gangguan jaringan dan adanya daftar harga tarif sewa warnet pada setiap bilik unit computer. Adapun aspek indikator shiddiq yang belum dinilai sesuai yaitu berkaitan dengan penyampaian kenaikan tarif yang tidak diinformasikan oleh pihak warnet kepada konsumen. Lebih lanjut dapat terlihat bahwa diantara 10 usaha yang menjadi obyek penelitian pada penerapan prinsip shiddiq terdapat 3 (tiga) usaha yang dalam penerapannya telah menerapkan seluruh indikator yang diteliti, yaitu FN, RN, dan DN.

Tabel 2 Penerapan Prinsip Berperilaku Benar dan Jujur pada Pengelolaan Warnet di Kota Kendari

\begin{tabular}{lllllrll}
\hline \multirow{2}{*}{ No } & \multirow{2}{*}{ Responden } & \multicolumn{4}{c}{ Indikator } & \multirow{2}{*}{$\%$} & \multirow{2}{*}{ Kategori } \\
\cline { 3 - 5 } & & 1 & 2 & 3 & & \\
\hline 1 & GHN & 1 & 1 & 0 & & 66.67 & Tinggi \\
2 & TN & 1 & 1 & 0 & & 66,67 & Tinggi \\
3 & FN & 1 & 1 & 1 & & 100,00 & Sangat Tinggi \\
4 & RN & 1 & 1 & 1 & & 100,00 & Sangat Tinggi \\
5 & GN & 1 & 1 & 0 & & 66,67 & Tinggi
\end{tabular}




\begin{tabular}{lllllrl}
6 & EN & 1 & 1 & 0 & 66.67 & Tinggi \\
7 & PN & 1 & 1 & 0 & 66,67 & Tinggi \\
8 & SN & 1 & 1 & 0 & 66.67 & Tinggi \\
9 & DN & 1 & 1 & 1 & 100,00 & Sangat Tinggi \\
10 & FAN & 1 & 1 & 0 & 66.67 & Tinggi \\
\hline & $\%$ & 100,00 & 100,00 & 30,00 & 76.67 & Tinggi \\
\hline
\end{tabular}

Sumber Data : Data Primer, 2019

Pada sisi lain, penerapan prinsip amanah pada pengelolaan usaha warnet di Kota Kendari dalam penelitian ini ditinjau berdasarkan 2 unsur yakni: (1) upaya pengelola memblokir situs yang mengandung pornografi dan pornoaksi; (2) tanggungjawab pengawasan terhadap terhadap upaya pembukaan situs yang mengandung pornografi dan pornoaksi serta kekerasan lainnya. Temuan penelitian menunjukkan bahwa dari 10 usaha yang diteliti, terdapat 4 usaha atau $40 \%$ yang berupaya melakukan pemblokiran situs yang mengandung pornografi dan pornoaksi, namun tak satupun yang melakukan pengawasan terhadap upaya pengaksesan situs-situs tersebut. Tabel 3 menunjukkan pula bahwa terdapat $60 \%$ usaha jasa layanan internet tidak melakukan upaya apapun dalam pengendalian situs-situs yang bertentangan dengan prinsip Islam, maupun sosial kemasyarakatan. Berdasarkan total indikator, diperoleh tingkat penerapan prinsip amanah berada pada nilai $20 \%$, dengan kategori sangat rendah.

\begin{tabular}{|c|c|c|c|c|c|}
\hline \multirow{2}{*}{ No } & \multirow{2}{*}{ Responden } & \multicolumn{2}{|c|}{ Indikator } & \multirow{2}{*}{$\%$} & \multirow{2}{*}{ Kategori } \\
\hline & & 1 & 2 & & \\
\hline 1 & GHN & 0 & 0 & 0 & Sangat Rendah \\
\hline 2 & $\mathrm{TN}$ & 0 & 0 & 0 & Sangat Rendah \\
\hline 3 & $\mathrm{FN}$ & 1 & 0 & 50,00 & Rendah \\
\hline 4 & RN & 1 & 0 & 50,00 & Rendah \\
\hline 5 & GN & 0 & 0 & 0 & Sangat Rendah \\
\hline 6 & EN & 0 & 0 & 0 & Sangat Rendah \\
\hline 7 & $\mathrm{PN}$ & 0 & 0 & 0 & Sangat Rendah \\
\hline 8 & $\mathrm{SN}$ & 1 & 0 & 50,00 & Rendah \\
\hline 9 & $\mathrm{DN}$ & 1 & 0 & 50,00 & Rendah \\
\hline 10 & FAN & 0 & 0 & 0 & Sangat Rendah \\
\hline & $\%$ & 40,00 & 0,00 & 20,00 & Sangat Rendah \\
\hline
\end{tabular}

Sumber Data : Data Primer, 2019

Temuan penelitian menunjukkan bahwa tingkat penerapan prinsip shiddiq dalam pengelolaan usaha jasa layanan internet berada pada kategori tinggi. Tingginya penerapan tersebut dibentuk oleh penyampaian informasi mengenai kerusakan/gangguan jaringan dan adanya daftar harga tarif sewa pada setiap bilik unit computer. Sifat shiddiq haruslah tertanam dalam jiwa seorang muslim, bukan hanya dalam berdagang, namun seluruh aspek kehidupan sebagaimana perintah untuk masuk ke dalam Islam secara keseluruhan sebagaimana yang tertuang dalam Qs. Al-Baqarah ayat 208. Ketidakjujuran dalam pandangan Islam hanya boleh dalam beberapa hal, yaitu: ketidakjujuran saat saat perang terutama kepada musuh, ketidakjujuran dalam upaya mendamaikan dua orang, dan ketidakjujuran perkataan suami kepada istri, atau sebaliknya agar tidak menyakiti hati pasangannya.

Kejujuran pengelola usaha sangat baik terlihat dari disampaikannya tarif jasa yang diberikan maupun kerusakan jaringan, namun masih perlu ditingkatkan dalam hal peenyampaian perubahan tarif sesegera mungkin. Padahal tidak dinformasikan perubahan tarif menjadikan transaksi tersebut mengandung unsur tadlis dimana salah satu pihak 
(dalam hal ini konsumen) tidak mengetahui harga jasa yang akan dibelikan. Transaksi tersebut tentunya merugikan pihak konsumen, meskipun nilainya kecil. Rasulullah secara jelas telah memberikan contoh perdagangan yang jujur sehingga tidak merugikan salah satu pihak, maupun keduanya. Pada sisi lain, Allah subhanahu wata'ala telah menggolongkan orang-orang yang berperilaku tidak jujur ke dalam golongan orang yang celaka sebagaimana yang termuat dalam Qs. Al Muthaffifin ayat 1-3, yang artinya: "Kecelakaan besarlah bagi orang-orang yang curang. (yaitu) orang-orang yang apabila menerima takaran dari orang lain mereka minta dipenuhi. dan apabila mereka menakar atau menimbang untuk orang lain, mereka mengurangi."

Kejujuran seorang muslim, haruslah dimotivasi oleh spiritualnya, bahwa kejujuran itu adalah perintah agama, bukan motivasi karena materi yang akan mendatangkan manfaat berupa peningkatan pelanggan dan keuntungan usaha. Sebab kejujuran adalah perintah agama, dan seorang muslim wajib mengikuti tuntunan agama, sebagaimana penjelasan Qs. Al Baqarah: 285. Keuntungan yang diperoleh pedagang karena berperilaku jujur adalah dampak dari kejujuran tersebut, bukan sebab kejujuran.

Lebih lanjut dapat terlihat bahwa diantara 10 usaha yang menjadi obyek penelitian pada penerapan prinsip shiddiq terdapat 3 (tiga) usaha yang dalam penerapannya telah menerapkan seluruh indikator yang diteliti, yaitu FN, RN, dan DN. Adapun aspek indikator shiddiq yang belum dinilai sesuai yaitu berkaitan dengan penyampaian kenaikan tarif yang tidak diinformasikan oleh pihak warnet kepada konsumen. Padahal sebelum melakukan transaksi, harga barang/jasa perlu diketahui dahulu. Temuan penelitian berbeda denga penelitian Maharani (2017) yang menemukan bahwa pedagang muslim telah sepenuhnya menerapkan prinsip kejujuran dalam usaha. Seorang yang jujur akan mampu melaksanakan tanggung jawab yang diberikan (Nizar, 2017).

Temuan penelitian menunjukkan bahwa dari 10 usaha yang diteliti, terdapat 4 usaha atau 40 persen yang berupaya melakukan pemblokiran situs yang mengandung pornografi dan pornoaksi, namun tak satupun yang melakukan pengawasan terhadap upaya pengaksesan situs-situs tersebut. Berdasarkan total indikator, diperoleh tingkat penerapan prinsip amanah berada pada kategori sangat rendah. Beberapa software dapat dimanfaatkan untuk memblokir situs-situs tertentu yang bisa merusak moral generasi muda, seperi: software K9 Web Protection, kemudian website filter. Cara lain juga yang dapat ditempuh seperti: mengatur ketinggian bilik agar tidak lterlalu tertutup (Sulaiman, 2011). Temuan penelitian ini sejalan dnegan studi yang dilakukan oleh Usnan (2019) yang menunjukkan bahwa para pedagang hanya mementingkan keuntungan belaka dan mengesampingkan masalah etika sehingga mengabaikan tanggungjawab sebagai pedagang. Namun temuan ini tidak sejalan dengan penelitian Maharani (2017) yang menemukan bahwa pedagang muslim telah sepenuhnya menerapkan prinsip tanggung jawab dalam usaha.

Perilaku tak pengabaian tanggung jawab moral terhadap eksternalitas negatif bisnis bukanlah perilaku yang terpuji. Pelaku usaha boleh saja berbisnis dengan tujuan mencari keuntungan maksimum, tetapi juga harus disertai dengan keuntungan sosial, sehingga pencapaian keuntungan sebesar-besarnya, berjalan seiring dengan pencapaian keberkahan. Sangat tidak berdasar jika ada yang beranggapan bahwa prinsip moralitas akan mengorbankan pencapaian keuntungan. Penelitian Anindya (2017) menunjukkan bahwa penerapan etika bisnis justru mendorong peningkatan laba. Temuan penelitian Akib \& Ernawati (2016) pelaku usaha yang menerapkan etika bisnis Islam termotivasi kesuksesan usaha dan harapan imbalan dari Allah. Pada sisi lain, dengan diterapkannya etika Islam dalam bisnis seperti: tauhid, keseimbangan, tanggung jawab, kehendak bebas, 
dan kebajikan menimbulkan dampak positif bagi proses operasional usaha, baik dalam aspek sumber daya manusia, pemasaran, lingkungan, sosial, dan serta finansial (Sampurno, 2016).

\section{KESIMPULAN}

Tingkat penerapan prinsip shiddiq dalam pengelolaan usaha jasa layanan internet di Kota Kendari berada pada penerapan syariah tinggi yakni sebesar 76.67 persen. Hal ini menunjukkan bahwa penerapan prinsip berperilaku benar dan jujur dalam pengelolaan jasa layanan internet belum 'kaffah', yang disebabkan oleh rendahnya keterbukaan pengelola usaha dalam penyampaian kenaikan tarif. Pada sisi lain, tingkat penerapan prinsip amanah dalam pengelolaan usaha jasa layanan internet di Kota Kendari berada pada penerapan syariah sangat rendah yakni sebesar 20.00 persen. Hal ini menunjukkan bahwa masih upaya pengelola untuk memblokir situs yang bertentangan dengan syariah, bahkan sangat lemah dalam pengawasan akses situs yang dapat merusak moral generasi muda. Adapun keterbatasan dalam penelitian ini adalah penggunaan indikator kejujuran terbatas pada aspek harga dan informasi; dan indikator amanah yang masih terbatas pada aspek pengawasan dan upaya pemblokiran situs.

\section{DAFTAR PUSTAKA}

Akib, N. \& Ernawati. (2016), Determinan Penerapan Etika Bisnis Islam di Kendari. Equilibrium, 4(1), 1-19

Alimuddin, Triyuwono, I., Irianto, G., \& Chandrarin, G. (2011), Konsep Harga Jual Kejujuran, Meraih Keuntungan Menggapai Kemaslahatan, Jurnal Akuntansi Multiparadigma, 2(1), 70-90

Almunadi . (2016). Shiddiq Dalam Pandangan Quraish Shihab. JIA. 17(1), 127-138.

Andjarwati, T. (2015). Motivasi dari Sudut Pandang Teori Hirarki Kebutuhan Maslow, Teori Dua Faktor Herzberg, Teori X Y Mc Gregor, dan Teori Motivasi Prestasi Mc Clelland, JMM17 Jurnal Ilmu Ekonomi \& Manajemen, 1(5), 45 - 54.

Anindya, D.A. (2017). Pengaruh Etika Bisnis Islam Terhadap Keuntungan Usaha Pada Wirausaha Di Desa Delituakecamatan Delitua . At-Tawassuth, 2(2), 389 - 412.

Baedowi, A. (2011).Etika Bisnis Perspektif Islam, Jurnal Hukum Islam, 9(2). Tersedia pada https://media.neliti.com/media/publications/37019-ID-etika-bisnisperspektif islam.pdf

Baharuddin. (2007). Paradigma Psikologi Islami: Studi tentang Elemen Psikologi dari alQur'an, cet. ke-2, Yogyakarta: Pustaka Pelajar.

Darmawati.(2012). Perilaku Jual Beli Di Kalangan Pedagang Kaki Lima Dalam Perspektif Etika Bisnis Islam (Studi Kasus Pedagang Buah-buahan di Kota Samarinda), Fenomena, 4(2), 127-138.

Djamil, F. (2013) Hukum Ekonomi Islam : Sejarah, Teori, dan Konsep, Jakarta: Sinar Grafika.

Djazuli, H.A. (2011). Kaedah-Kaedah Fiqh: Kaedah-kaedah Hukum Islam dalam Menyelesaikan Masalah-masalah yang Praktis, Cetakan IV, Jakarta: Kencana Prenada Media Group.

Hafidz, M.S., Sya'roni, S. \& Marlina. (2012).Etika Bisnis Al-Ghazali dan Adam Smith Dalam Perspektif Ilmu Bisnis Dan Ekonomi. Jurnal Penelitian, 9(1), 18-34.

Lahuri, S. (2013). Corporate Social Responsisbility Dalam Perspektif Islam. Tsaqofah, 7(2), 219-237. 
Lisnawati, Y., Abdussalam, A. dan Wibisana, W. (2015). Konsep Khalīfah Dalam AlQur'Ān Dan Implikasinya Terhadap Tujuan Pendidikan Islam (Studi Maudu'i Terhadap Konsep Khalīfah Dalam Tafsir Al-Misbah), Tarbawy, 2(1), 47-57

MUI. (2005). Fatwa Majelis Ulama Indonesia Nomor: 6/MUNAS VII/MUI/10/2005 Tentang Kriteria Maslahat. Tersedia pada http://mui.or.id/wpcontent/uploads/files/fatwa/40.-Kriteria-Maslahat.pdf

Maharani, D. (2017). Penerapan Kejujuran Dan Tanggung Jawab Dalam Etika Bisnis Syariah Pada Wirausaha Muslim Di Kecamatan Medan Marelan, Intiqad, 9(1), 21-29

Nizar, M. (2017). Prinsip Kejujuran Dalam Perdagangan Versi Alqur'an, MAFHUM: Jurnal Ilmu al-Qur'an dan Tafsir, 2(2), 309-320.

Norvadevi. (2015). Bisnis dalam Perspektif Islam (Telaah Konsep, Prinsip dan Landasan Normatif). Al-Tijary, 1(1), 33-46.

Prihartanta, W. (2015). Teori-Teori Motivasi. Jurnal Adabiya, Vol. 1(83), 1-11.

Rahmawaty, A. (2012). Model Perilaku Penerimaan Internet Banking Di Bank Syari'ah: Peran Motivasi Spiritual, Conference proceeding, Annual International Conference onf Islamic Studies (AICIS XII), Surabaya, 5-8 November, hal. 17841807, tersedia pada https://core.ac.uk/download/pdf/34212375.pdf

Riduwan. 2015. Skala Pengukuran Dalam Penelitian. Bandung : Alfabeta.

Sampurno, W.M. (2016). Penerapan etika bisnis Islam dan dampaknya terhadap kemajuan bisnis industri rumah tangga , Journal of Islamic Economics Lariba, 2(1), 13-18.

Sulaiman, A.I. (2011). Konstruksi makna Dampak Media Internet Penggunaan Media Internet oleh Pelajar di Kota Purwokerto Kabupaten Banyumas (Studi Deskriptif Kualitatif Para Pelajar di Kota Purwokerto Kabupaten Banyumas). Jurnal Penelitian Komunikasi, 14(1), 53-62.

Usnan. (2019). Implementasi Prinsip Ekonomi Islam oleh Pedagang dalam Melakukan Penimbangan Sembako di Pasar Bagan Hulu Rokan Hilir, Al-Mutharahah, 16(2), 434-456

Yusanto, M.I. \& Widjajakusuma, M.K. (2002). Menggagas Bisnis Islami. Jakarta: Gema Insani Press. 